\title{
Efektivitas kelompok diskusi tutorial problem based learning di Fakultas Kedokteran Universitas Sam Ratulangi
}

\author{
${ }^{1}$ Virgin E. Pioh \\ ${ }^{2}$ Yanti Mewo \\ ${ }^{2}$ Siemona Berhimpon
}

\author{
${ }^{1}$ Kandidat Skripsi Fakultas Kedokteran Universitas Sam Ratulangi Manado \\ ${ }^{2}$ Medical Education Unit Fakultas Kedokteran Universitas Sam Ratulangi Manado \\ Email: Enjelpioh12251@yahoo.com
}

\begin{abstract}
The Faculty of Medicine, Sam Ratulangi University has applied the Problem Based Learning (PBL) method in which the tutorial group discussion is the center in this learning method. The purpose of PBL is to improve the students' problem solving skill which is essential for the students who are going to be professional medical practitioners in the future. Therefore, the effectiveness of the tutorial group discussion of PBL must be implemented in order to achieve the learning goalsThe cognitive aspect is related to the students' knowledge whilst the motivational aspect is dealing with the factors which enforce the students to perform better in learning. This study aimed to obtain the effectiveness of the tutorial group discussion of PBL at the Faculty of Medicine, Sam Ratulangi University. This study employed the Tutorial Group Effectiveness Instrument (TGEI) questionnaire which included the motivational aspects, cognitive aspect, and demotivational aspect. This TGEI (Indonesian language version) questionnaire was distributed to 40 students from class of 2015 who fulfilled the inclusive criteria before the seminar (the plenary) of Biophysics module. The results showed that the effectiveness of the tutorial group discussion of PBL was good by the majority of students (95\%). In particular, the cognitive aspect, motivational aspect and demotivational aspect were rated good by the students for about $87.5 \%, 92.5 \%$ and $70 \%$, respectively. Conclusion: In general, the effectiveness of the tutorial group discussion of PBL at the Faculty of Medicine, Sam Ratulangi University was good.
\end{abstract}

Keywords: tutorial group, effectiveness, collaborative, TGEI

\begin{abstract}
Abstrak: Fakultas Kedokteran Universitas Sam Ratulangi telah menerapkan metode pembelajaran Problem based learning (PBL). Kelompok diskusi tutorial menjadi inti dalam PBL yang bertujuan untuk meningkatkan kemampuan mahasiswa dalam memecahkan masalah. Sebagai mahasiswa calon profesi dokter, kemampuan memecahkan masalah menjadi modal utama dalam menjalani profesi dimasa depan. Penelitian ini bertujuan untuk mengetahui efektivitas kelompok diskusi tutorial PBL di Fakultas Kedokteran Universitas Sam Ratulangi. Penelitian ini menggunakan kuesioner Tutorial Group Effectiveness Instrument (TGEI) yang didalamnya mencakup aspek motivasi, aspek kognitif, dan aspek demotivational. Kuesioner TGEI (versi bahasa Indonesia) dibagikan kepada 100 mahasiswa angkatan 2015 yang masuk kriteria inklusi sebelum seminar (pleno) Modul Biofisika. Hasil penelitian menunjukkan bahwa, sebagian besar (95\%) mahasiswa memberikan pernyataan dengan penilaian terhadap efektivitas kelompok diskusi tutorial PBL ialah baik. Bila dilihat dari ketiga aspek yang dijadikan dasar penilaian efektivitas, 87,5\% mempunyai penilaian baik untuk aspek kognitif, 92,5\% mempunyai penilaian baik untuk aspek motivasi, dan $70 \%$ mempunyai penilaian baik untuk aspek demotivational. Simpulan: Secara umum, efektivitas kelompok diskusi tutorial PBL di Fakultas Kedokteran Universitas Sam Ratulangi ialah baik.

Kata kunci: kelompok tutorial, efektivitas, kolaboratif, TGEI
\end{abstract}


Metode belajar merupakan penunjang efektivitas pembelajaran. Pengertian metode belajar adalah perencanaan secara menyeluruh untuk menyajikan materi pembelajaran secara prosedural. Prosedural artinya, penerapan suatu metode dalam pembelajaran dikerjakan dengan langkah-langkah yang teratur dan secara bertahap, dimulai dari penyusunan perencanaan pembelajaran, penyajian bahan pembelajaran, proses, sampai penilaian hasil belajar. ${ }^{1}$ Metode belajar merupakan upaya yang dilakukan oleh para pendidik agar proses belajar mengajar pada siswa tercapai sesuai dengan tujuan. ${ }^{2}$

Salah satu metode belajar yaitu metode pembelajaran Problem Based Learning (PBL). Problem Based Learning adalah pembelajaran yang menggunakan masalah sebagai fokus belajar agar mahasiswa berpikir kritis dan mampu memecahkan masalah. ${ }^{3}$ Pembelajaran kolaboratif menjadi salah satu prinsip dalam PBL. Pada pembelajaran kolaboratif mahasiswa berinteraksi secara aktif dan memberi umpan balik sebagai prasarana mengembangkan pengetahuan yang sudah ada dengan pengetahuan baru. Terdapat empat aspek dalam pembelajaran kolaboratif yaitu aspek motivasi, kohesif, perspektif dan kognitif. Dua aspek utama yang mempengaruhi kelompok belajar yaitu aspek kognitif dan motivasi. ${ }^{4}$

Tutorial merupakan bagian utama dari PBL. Kemandirian mahasiswa menjadi prinsip kegiatan tutorial. Tutorial adalah proses belajar dengan bimbingan tutor kepada mahasiswa, yang bertujuan meningkatkan belajar mandiri mahasiswa. Tutorial tidak akan berjalan maksimal bila mahasiswa tidak aktif dalam suatu kelompok. Untuk itu tujuan tutor mendorong setiap mahasiswa mengambil peran selama diskusi. ${ }^{5}$ Efektivitas kelompok tutorial harus dipastikan karena menentukan kesuksesan pembelajaran dalam PBL. Efektivitas tutorial PBL dipengaruhi oleh tiga aspek dasar yaitu, mahasiswa, tutor, dan scenario. ${ }^{6}$

Sasaran penelitian efektivitas kelompok diskusi tutorial PBL ialah mahasiswa.
Penelitian sejenis pernah dilakukan oleh Mewo $^{7}$ pada tahun 2011 di Fakultas Kedokteran Universitas Sam Ratulangi. Subjek penelitian yaitu mahasiswa semester empat dengan jumlah sampel yaitu 296 mahasiswa. Hasil penelitian didapatkan persepsi mahasiswa terhadap efektivitas kelompok tutorial ialah baik menurut sebagian besar mahasiswa (70\%). Meski persepsi mahasiswa sudah baik, bila dilihat dari tiga aspek yang mempengaruhi efektivitas kelompok tutorial, masih terdapat aspek dengan nilai persepsi sebagian besar kurang (52\%) yaitu pada aspek demotivational.

Saat ini peneliti melakukan penelitian sejenis, namun pada penelitian ini dilakukan pada mahasiswa semester satu atau angkatan 2015 dengan perbandingan jumlah anggota kelompok tutorial yang berbeda, pada penelitian sebelumnya jumlah 14-20 mahasiswa, ${ }^{7}$ sedangkan penelitian ini jumlah 10-11 mahasiswa. Penelitian berfokus pada dua aspek utama pada pembelajaran kolaboratif yang mempengaruhi kelompok diskusi, yaitu aspek kognitif dan aspek motivasi. Kedua aspek tersebut dikembangkan oleh Singaram et al. ${ }^{8}$ menjadi komponen penilaian terhadap efektivitas kelompok diskusi tutorial PBL dalam instrument yang disebut Tutorial Group Effectiveness Instrument (TGEI).

Penilaian terhadap efektivitas kelompok diskusi tutorial dapat menjadi bahan evaluasi terhadap hal-hal yang perlu diperbaiki yang memengaruhi berkurangnya efektivitas kelompok diskusi tutorial PBL. Efektivitas kelompok diskusi tutorial PBL meningkatkan kemampuan mahasiswa dalam memecahkan masalah. Khususnya bagi mahasiswa kedokteran, akan sangat berguna sebagai bekal mempersiapkan diri dimasa depan atau sebagai calon dokter. Keterampilan dalam pemecahan masalah menjadi modal penting seorang dokter saat menghadapi kasus nyata pada pasien.

Penulis memakai mahasiswa sebagai fokus penelitian karena proses diskusi kelompok sangat dipengaruhi oleh tiga aspek yang ada pada mahasiswa, yaitu 
aspek kognitif, motivasi, dan demotivational. Hal ini terbukti dari pengalaman penulis sendiri. Banyak anggota kelompok yang kurang termotivasi dalam diskusi kelompok tutorial sehingga menjadi kurang aktif atau hanya berkontribusi sedikit selama diskusi berlangsung. Selain itu, kesadaran anggota kelompok atas tanggung jawab terhadap keberhasilan kelompok juga masih kurang sehingga banyak anggota yang tidak mengerjakan tugas kelompoknya. Hal-hal tersebut yang mempengaruhi efektivitas kelompok diskusi tutorial menjadi berkurang. Dari ketiga aspek tersbut ada juga hal-hal yang mempengaruhi misalnya, jumlah anggota kelompok dan tutor dalam kelompok tersebut. Dari pengalaman penulis, jumlah anggota kelompok ialah 17-18 orang dengan kehadiran tutor yaitu tutor tetap dan terkadang tutor rangkap.

Pada mahasiswa angkatan 2015 jumlah anggota kelompok tutorial mendekati jumlah ideal anggota kelompok yaitu 10-11 orang. Berdasarkan hal tersebut peneliti tertarik melakukan penelitian mengenai efektivitas kelompok disuksi tutorial Problem Based Learning di Fakultas Kedokteran Universitas Sam Ratulangi dengan mengambil kelompok tutorial dengan kehadiran tutor tetap untuk diteliti.

\section{METODE PENELITIAN}

Penelitian ini menggunakan kuesioner yang dikembangkan oleh Singaram et al. ${ }^{8}$ yaitu Tutorial Group Effectiveness Instrument (TGEI)(7). TGEI terdiri dari 19 pernyataan, dengan tiga aspek penilaian yaitu: 1) aspek kognitif yang terdiri dari tujuh pernyataan (nomor 1-7); 2) aspek motivasi terdiri dari 7 pernyataan (nomor 8-14); dan 3) aspek demotivational, lima pernyataan (15-19). Validitas dan reliabilitas TGEI versi Bahasa Indonesia telah dibuktikan oleh Mewo ${ }^{7}$ dengan nilai koefisien alfa 0.82 untuk faktor kognitif dan motivasi, 0.64 untuk faktor demotivatioanl, dan 0.79 untuk keseluruhan pernyataan.

\section{HASIL PENELITIAN \\ Karakteristik Subyek}

Berdasarkan penelitian yang dilakukan pada mahasiswa angkatan 2015 Fakultas Kedokteran Universitas Sam Ratulangi Manado, terdapat sejumlah 106 mahasiswa menandatangani surat persetujuan (informed consent) yang berarti bersedia berpartisipasi dalam penelitian. Saat pembagian lembaran kuesioner TGEI (versi bahasa Indonesia), 6 mahasiswa tidak hadir sehingga jumlah mahasiswa yang menerima lembaran ialah 100 mahasiswa. Berdasarkan kriteria inklusi, hanya empat kelompok tutorial yang memenuhi yaitu, kelompok 1 jumlah 11 mahasiswa, kelompok 2 jumlah 11 mahasiswa, kelompok 6 jumlah 10 mahasiswa, kelompok 7 jumlah 11 mahasiswa, dengan total keseluruhan yaitu 43 mahasiswa. Tiga diantaranya termasuk mahasiswa yang tidak hadir saat penyebaran kuesioner sehingga tersisa 40 mahasiswa yang diambil menjadi sampel.

Sesuai data penelitian, dilihat dari jenis kelamin sebesar $60 \%$ sampel yaitu perempuan. Rentang usia seluruh sampel berada pada 14-19 tahun dengan rerata usia 18 tahun (Tabel 1).

Tabel 1. Sebaran subyek menurut umur dan jenis kelamin

\begin{tabular}{cccc}
\hline $\begin{array}{c}\text { Karakte- } \\
\text { ristik }\end{array}$ & $\mathrm{n}(\%)$ & $\begin{array}{c}\text { Rerata } \pm \\
\text { SD }\end{array}$ \\
\hline Umur & & & $18 \pm 1$ \\
Jenis & Laki-laki & $16(40 \%)$ & \\
Kelamin & Perempuan & $24(60 \%)$ & \\
\hline
\end{tabular}

\section{Aspek Kognitif}

Berdasarkan data yang ada lebih banyak aspek kognitif berada pada pernyataan dengan penilaian baik $(87,5 \%)$ atau dapat dikatakan penilaian kelompok diskusi tutorial PBL dari aspek kognitif sebagian besar efektif (Tabel 2).

Dari ketujuh pernyataan untuk menilai aspek kognitif, seluruh sampel (100\%) setuju dengan pernyataan nomor 7 Sebaliknya, pernyataan yang paling banyak tidak disetujui (15\%) mahasiswa ada pada pernyataan nomor 1 dan 2 (Gambar 1). 
Pioh, Mewo, Berhimpon: Efektivitas kelompok diskusi...

Tabel 2. Penilaian aspek kognitif terhadap efektivitas kelompok

\begin{tabular}{|c|c|c|c|}
\hline Penilaian & $n$ & \multicolumn{2}{|l|}{$\%$} \\
\hline Kurang & 5 & \multicolumn{2}{|l|}{12,5} \\
\hline Baik & 35 & \multicolumn{2}{|l|}{87,5} \\
\hline Total & 40 & \multicolumn{2}{|l|}{100} \\
\hline 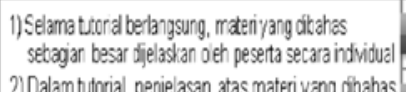 & 15 & \multicolumn{2}{|c|}{85 티 setuju } \\
\hline 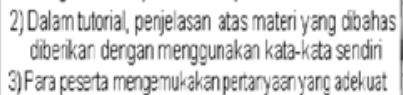 & 15 & \multicolumn{2}{|c|}{$85=$ tidak } \\
\hline 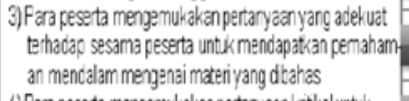 & 10 & \multicolumn{2}{|c|}{90} \\
\hline 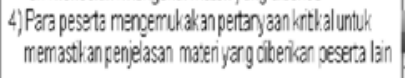 & 13 & \multicolumn{2}{|c|}{87} \\
\hline $\begin{array}{l}\text { 5;,Dalam kelompok kutonial, saya belajar banyak dari } \\
\text { kontribusis sesama anggota kelompok }\end{array}$ & 3 & \multicolumn{2}{|r|}{97} \\
\hline $\begin{array}{l}\text { 6), Dalem kelompol tutcrial, salath pengertian terhadap } \\
\text { mater ok okoreksioeh anggota kelompok lainnya }\end{array}$ & 10 & \multicolumn{2}{|c|}{90} \\
\hline \multirow[t]{2}{*}{ 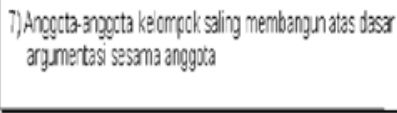 } & & \multicolumn{2}{|r|}{100} \\
\hline & $0 \%$ & & $10 \%$ \\
\hline
\end{tabular}

Gambar 1. Grafik sebaran subyek menurut komponen aspek kognitif (No. 1-7)

\section{Aspek Motivasi}

Efektivitas kelompok diskusi tutorial dilihat dari aspek motivasi yaitu baik dengan hasil persentase 92,5\% (Tabel 3).

Tabel 3. Penilaian aspek motivasi terhadap efektivitas kelompok

\begin{tabular}{ccc}
\hline Penilaian & $\mathrm{n}$ & $\%$ \\
\hline Kurang & 3 & 7,5 \\
Baik & 37 & 92,5 \\
\hline Total & 40 & 100 \\
\hline
\end{tabular}

Terdapat 97\% mahasiswa yang setuju pada pernyataan nomor 8 . Pernyataan yang paling banyak tidak disetuju (15\%) terdapat pada pernyataan nomor 14 (Gambar 2)

\section{Aspek Demotivational}

Pernyataan demotivational atau pernyataan nomor 15-19 merupakan bentuk pernyataan terbalik atau pernyataan negatif untuk menilai efektivitas kelompok diskusi tutorial PBL. Pada aspek demotivational terdapat $70 \%$ penilaian baik terhadap efektivitas kelompok dan hanya 30\% saja yang kurang (Tabel 4).

Dilihat dari jumlah pernyataan pada aspek demotivational, 85\% mahasiswa paling banyak tidak setuju dengan pernyataan nomor 18 sedangkan pernyataan yang paling banyak disetujui (60\%) pada pernyataan nomor 15 (Tabel 4, Gambar 3)

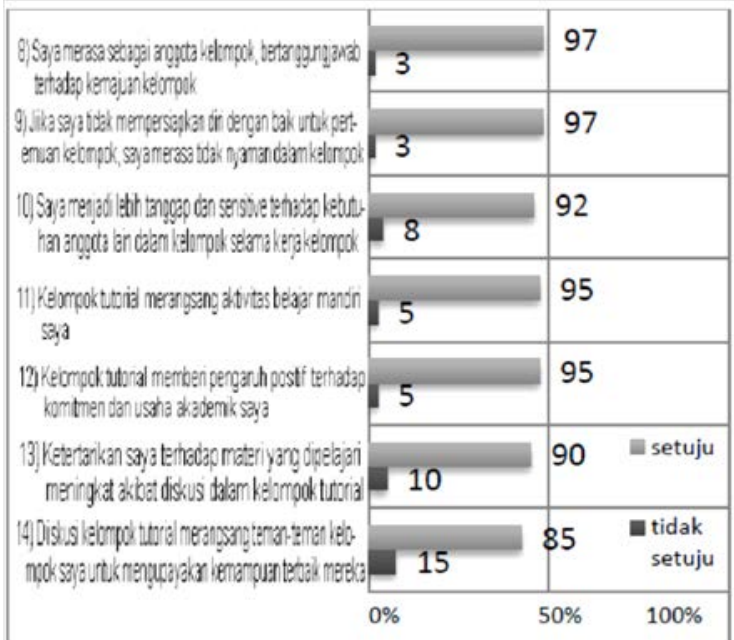

Gambar 2. Grafik sebaran subyek menurut komponen aspek motivasi (No. 8 s.d. 14)

Tabel 4. Penilaian aspek demotivational terhadap efektivitas kelompok

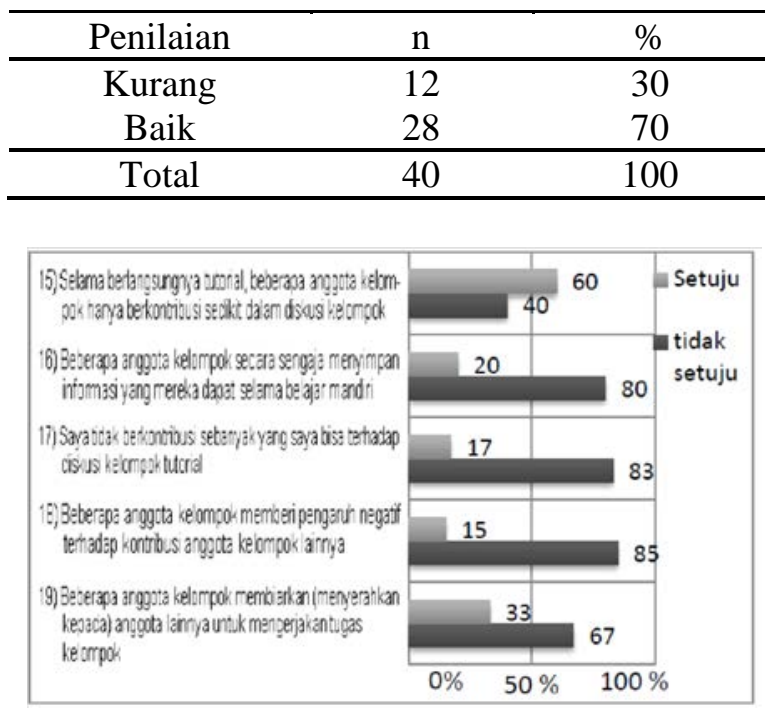

Gambar 3. Grafik sebaran subyek menurut komponen aspek demotivational (No. 15-19)

\section{Efektivitas kelompok}

Penilaian efektivitas kelompok diskusi tutorial PBL pada penelitian ini berdasarkan pada tiga aspek, yaitu kognitif, motivasi, demotivational, atau menggunakan pernyataan nomor 1-19 dari kuesioner TGEI. Berdasarkan hasil menunjukkan 
bahwa, efektivitas kelompok secara keseluruhan yaitu baik (95\%) dapat dilihat pada Tabel 5.

Tabel 5. Penilaian efektivitas kelompok secara keseluruhan

\begin{tabular}{ccc}
\hline Persepsi & $\mathrm{n}$ & $\%$ \\
\hline Kurang & 2 & 5 \\
Baik & 38 & 95 \\
Total & 40 & 100 \\
\hline
\end{tabular}

\section{BAHASAN}

Penilaian terhadap efektivitas kelompok diskusi tutorial PBL yaitu baik, dilihat dari sebagian besar (95\%) pernyataan responden. Dilihat dari ketiga aspek yang mempengaruhi efektivitas kelompok diskusi tutorial yaitu aspek kognitif, motivasi, dan demotivational, ketiganya dikategorikan baik. Dengan kata lain, efektivitas kelompok diskusi tutorial PBL di Fakultas Kedokteran Universitas Sam Ratulangi khususnya pada Angkatan 2015 adalah baik. Baik dari aspek kognitif yaitu aspek yang berkaitan dengan pengetahuan mahasiswa, maupun aspek motivasi yaitu aspek positif yang mendukung keberhasilan kelompok dengan memotivasi mahasiswa meningkatkan kemampuan belajar, ${ }^{4}$ sedangkan aspek demotivational yang merupakan aspek negatif tidak memengaruhi berkurangnya efektivitas kelompok diskusi tutorial PBL di Fakultas Kedokteran Universitas Sam Ratulangi. Meskipun aspek demotivational baik, bila dibandingkan dengan dua aspek lain yaitu motivasi (92,5\%) dan kognitif (87,5\%), aspek demotivational memiliki nilai paling rendah (70\%). Adapun aspek demotivational merupakan aspek yang memberikan dampak negatif terhadap peningkatan kemampuan belajar dan keberhasilan kelompok.

Sebagian besar sampel memiliki pernyataan baik pada ketiga aspek ini, sehingga efektivitas kelompok tutorial menjadi baik. Namun dibalik itu, ada beberapa pernyataan yang justru tidak disetujui oleh responden.

Bila dilihat dari aspek kognitif, pernyataan tidak setuju paling banyak (15\%) ada pada pernyataan nomor 1 dan 2. Pernyataan nomor 1 bahwa, selama tutorial materi yang dibahas sebagian besar dijelaskan oleh anggota kelompok secara individual. Salah satu prasyarat penting dalam proses diskusi kelompok adalah komunikasi. Keberhasilan diskusi akan tercapai bila seluruh anggota memberikan masukan demi keberhasilan kelompoknya. Oleh karena itu anggota kelompok yang aktif merupakan hal pendukung efektivitas pembelajaran khususnya dalam suatu kelompok diskusi. ${ }^{9}$ Mahasiswa yang tidak aktif dalam kelompok menjadikan diskusi tutorial tidak efektif. Pernyataan kedua yang banyak tidak disetujui responden yaitu, dalam tutorial penjelasan atas materi yang dibahas diberikan dengan menggunakan kata-kata sendiri. Dengan diskusi mahasiswa belajar untuk berbicara memberikan alasan atas jawaban atau pernyataanya. ${ }^{10}$ Bila dikaitkan dengan pernyataan nomor dua, mahasiswa lebih dituntut memberikan penjelasan atas materi yang dibahas dengan menggunakan katakata sendiri atau tidak berdasarkan textbook. Ada beberapa kemungkinan yang membuat mahasiswa lebih memilih menjelaskan materi berdasarkan kata-kata buku. Kemungkinan pertama karena mahasiswa tidak menguasai dengan baik apa yang akan dijelaskan, dan kemungkinan kedua karena faktor internal mahasisiswa, seperti rasa takut berbicara, takut salah menjelaskan, dan tidak percaya diri. $^{11}$

Pada aspek motivasi, 15\% mahasiswa tidak setuju bahwa diskusi kelompok tutorial merangsang anggota lain untuk mengupayakan kemampuan terbaik mereka. Diskusi kelompok dapat diartikan sebagai bentuk kerjasama dalam proses pembelajaran. Dalam hal ini, setiap anggota berperan dalam mencapai keberhasilan kelompok. Peran nyata yang harus dilakukan salah satunya dengan mengupayakan kemampuan terbaik mereka. $^{12}$ Kemampuan seseorang dalam kelompok dapat disalurkan dengan mengoptimalkan seluruh pengetahuan yang 
mereka miliki untuk dibahas dalam diskusi tutorial. Mahasiswa yang tidak mengupayakan kemampuan terbaik mereka berarti keinginan untuk mencapai keberhasilan kelompok masih kurang.

Yang terakhir aspek demotivational yang merupakan aspek negatif yang mempengaruhi efektivitas kelompok diskusi tutorial. Sebanyak 60\% mahasiswa setuju dengan pernyataan negatif bahwa, beberapa anggota kelompok hanya berkontribusi sedikit dalam diskusi kelompok. Dalam kelompok diskusi tutorial, mahasiswa dituntut untuk lebih banyak berkontribusi dibanding tutor. Tutor hanya mengawasi kelancaran proses diskusi. Itulah sebabnya, kemandirian mahasiswa menjadi prinsip pokok diskusi tutorial. Mahasiswa yang berkontribusi sedikit dalam tutorial dikarenakan kurangnya persiapan sebelum menghadapi diskusi tutorial. ${ }^{5}$ Pernyataan kedua terbanyak yang disetujui pada pernyataan aspek demotivational bahwa, beberapa anggota kelompok membiarkan atau menyerahkan anggota lain mengerjakan tugas kelompok. Pembelajaran kolaboratif melatih mahasiswa bekerjasama dalam kelompoknya untuk mencapai tujuan pembelajaran. Anggota kelompok bersamasama bertanggung jawab sepenuhnya atas pembelajaran yang mereka laksanakan. Dengan demikian keberhasilan kelompok ditentukan oleh usaha dari setiap anggota kelompok itu sendiri. Tugas kelompok menjadi tanggung jawab bersama keberhasilan kelompok. Rasa tanggung jawab didukung oleh motivasi dalam diri mahasiswa. Apabila tidak ada motivasi maka mahasiswa tidak memiliki keinginan dan tidak tertarik untuk belajar bahkan mengerjakan tugas. ${ }^{13}$

Idealnya kelompok diskusi akan lebih efektif bila anggota kelompok berjumlah 810 mahasiswa. ${ }^{13}$ Terbukti dengan melihat pencapaian efektivitas kelompok diskusi yang telah dilakukan. Pada penelitian oleh Mewo $^{7}$ nilai efektivitas didapatkan sebagian besar $70 \%$ ialah baik dengan jumlah anggota kelompok 14-20 mahasiswa. Penelitian oleh Vina ${ }^{14}$ mandapatkan 58,94\% baik dengan jumlah anggota kelompok 12-13 mahasiswa, dan pada penelitian ini nilai efektivitas kelompok jauh lebih tinggi yaitu 95\% baik dengan jumlah anggota kelompok 10-11 mahasiswa atau mendekati jumlah ideal dari suatu kelompok diskusi. Akan tetapi, efektivitas kelompok diskusi tutorial PBL tidak hanya dipengaruhi oleh jumlah anggota kelompok saja. Efektivitas kelompok diskusi tutorial PBL didukung oleh tiga aspek, dan ada banyak hal yang mempengaruhi aspek-aspek tersebut.

Aspek kognitif, yaitu aspek yang berkaitan dengan pengetahuan mahasiswa. Pernyataan aspek kognitif menggambarkan mahasiswa harus aktif menyampaikan pemikiran atau pengetahuannya selama diskusi kelompok. Peran tutor sangat mempengaruhi aspek kognitif mahasiswa selama tutorial berlangsung. Salah satu peran tutor yaitu memastikan kelompok mencapai tujuan belajar, sehingga tutor harus mendorong anggota kelompok untuk aktif selama proses diskusi tutorial. Salah satu hal yang perlu diperhatikan untuk mendukung tujuan dari peran tutor yaitu, tutor perlu memahami karakterisitk anggota kelompoknya. ${ }^{13}$ Supaya peran tutor lebih efektif, maka sebaiknya tutor mengambil peran berfokus pada satu ruangan saja dan mengikuti proses diskusi kelompok pada setiap kegiatan tutorial berlangusng. Peran tutor yang efektif akan mempengaruhi efektivitas kelompok diskusi tutorial PBL khususnya pada aspek kognitif. Hal ini jelas terlihat pada penelitian ini untuk aspek kognitif lebih tinggi 87,5\% karena difasilitasi oleh tutor yang sama selama tutorial berlangsung, sedangkan penelitian sebelumnya yang masih difasilitasi oleh tutor rangkap juga baik namun dengan nilai persentase lebih rendah, yaitu pada $\mathrm{Mewo}^{7}$ dengan nilai $77 \%$ dan Vina ${ }^{14}$ dengan nilai $79,47 \%$.

Minat menjadi dasar utama seseorang menentukan kemana dia melanjutkan study. ${ }^{15}$ Minat dalam Kamus Besar Bahasa Indonesia berarti kecenderungan, gairah, atau keinginan hati yang tinggi terhadap sesuatu. ${ }^{16}$ Dalam hal ini secara tidak 
langung, minat mempengaruhi motivasi dalam diri seseorang. Mahasiswa dalam memilih jurusan didasari oleh minatnya, sehingga motivasi belajar mahasiswa tinggi. Adapun faktor intrinsik yang mendukung motivasi belajar mahasiswa ialah memilih bidang studi yang paling disenangi dan paling sesuai dengan minat, memilih jurusan bidang studi yang sesuai dengan bakat dan pengetahuan, dan memilih bidang studi yang paling menunjang masa depan. Sedangkan faktor ekstrinsik yang mendukung yaitu, keinginan menjaga harga diri atau gengsi misalnya ingin dianggap sebagai orang pandai, keinginan untuk menang bersaing dengan orang lain, keinginan untuk dikagumi sebagai orang yang berprestasi, dorongan dari orang tua, dosen, atau teman. Perlu diketahui bahwa, motivasi belajar yang timbul dari dalam diri mahasiswa (intrinsik), akan jauh lebih baik dari motivasi yang muncul dari luar (ekstrinsik). Hal ini disebabkan karena motivasi belajar yang tergantung pada faktor luar, biasanya motivasi belajar mahasiswa cenderung tidak stabil dan mudah menjadi lemah. Jika menghadapi pengajaran hambatan tertentu, seperti menghadapi pengajar yang tidak disenangi, tidak ada dorongan orang lain, adanya gangguan emosi yang timbul karena masalah pribadi maka motivasi belajar mahasiswa bisa hilang. Hal inilah yang mendukung aspek demotivational. ${ }^{17}$ Dilihat dari hasil penelitian ternyata tingkat semester mahasiswa mempengaruhi penilaian terahadap aspek motivasi. Penelitian yang dilakukan oleh $\mathrm{Mewo}^{7}$ didapatkan penilaian untuk aspek motivasi pada mahasiswa semester empat hanya $76 \%$ baik, sedangkan pada mahasiswa semester dua penelitian oleh Vina ${ }^{14}$ nilai motivasi cukup tinggi yaitu $89,2 \%$ baik, dan penelitian ini pada semester satu aspek motivasi mahasiswa tinggi $92,5 \%$ baik. Bagi mahasiswa semester awal motivasi belajar masih tinggi baik dari faktor intrinsik maupun ekstrinsik. Namun sesuai pembahasan di atas, motivasi mahasiswa yang di dasari oleh faktor ekstrinsik dapat membuat motivasi belajar mahasiswa lama kelamaan hilang. Hal inilah yang memengaruhi motivasi belajar pada mahasiswa semester awal lebih tinggi dibandingkan mahasiswa semester lanjut.

Motivasi belajar mahasiswa masih berkaitan dengan aspek demotivational. Untuk pernyataan aspek demotivational lebih membahas mengenai hal-hal yang menghambat motivasi belajar mahasiswa dan keberhasilan kelompok. Pernyataan demotivational merupakan bentuk pernyataan negatif. Pembahasan untuk aspek demotivational erat kaitannya dengan motivasi mahasiswa yang muncul dari luar diri atau ekstrinsik. Seperti yang telah dijelaskan sebelumnya, motivasi yang muncul dari luar tidak akan bertahan bila dipengaruhi oleh beberapa faktor yang menghambat. ${ }^{17}$ Dari hasil penelitian untuk aspek demotivational, pada penelitian ini sebagian besar penilaian masih baik (70\%) terhadap efektivitas kelompok tutorial. Penelitian oleh Mewo ${ }^{7}$ sebagian besar penilainnya yaitu kurang (52\%) terhadap efektivitas kelompok tutorial, dan pada penelitian Vina $^{14}$ sebagian besar juga kurang (79,73\%) terhadap efektivitas kelompok tutorial. Motivasi belajar mahasiswa dipengaruhi oleh hal apa yang ingin dipelajari. Apabila ada dorongan atau keingingan untuk mempelajari sesuatu maka mahasiswa akan bekerja keras sehingga mencapai apa yang diinginkannya. ${ }^{13}$ Bila dilihat dari proses penelitian, setiap peneliti mengambil data pada blok atau modul yang berbeda-beda. Kemungkinan hal ini juga mempengaruhi aspek motivasi atau keinginan belajar mahasiswa. Bila tidak didasari oleh keinginan untuk apa yang hendak dipelajari, maka hal itulah yang mendukung aspek demotivational mempengaruhi efektivitas kelompok diskusi tutorial PBL.

\section{SIMPULAN}

1. Efektivitas kelompok diskusi tutorial Problem Based Learning di Fakultas Kedokteran Universitas Sam Ratulangi umumnya baik.

2. Dilihat dari ketiga aspek yaitu kognitif, 
motivasi, demotivational yang memengaruhi efektivitas kelompok diskusi tutorial Problem Based Learning, ketiganya diperoleh penilaian baik (Kognitif 87,5\%, motivasi 92,5\%, demotivational 70\%).

\section{SARAN}

1. Bagi mahasiswa, diharapkan mempersiapkan diri dengan baik sebelum menghadapi tutorial supaya saat menghadapi diskusi kelompok mahasiswa bisa memberi diri berkontribusi dengan baik. Mahasiswa juga harus menyeimbangkan rasa tanggung jawab atas kemajuan kelompok dengan tidak membiarkan anggota kelompok lain mengerjakan tugas kelompok.

2. Bagi tutor, diharapkan memperhatikan hal-hal yang memengaruhi berkurangnya efektivitas kelompok diskusi tutorial PBL, antara lain, dengan mendorong setiap mahasiswa dalam berkontribusi dan merangsang mahasiswa mengupayakan kemampuan terbaik mereka. Saat proses diskusi kelompok, tutor sebaiknya membiasakan mahasiswa menjelaskan materi dengan menggunakan kata-kata sendiri berdasarkan pemahaman materi yang dijelaskan.

3. Bagi institusi, supaya memperhatikan kehadiran dan pembagian tutor disetiap kelompok tutorial, karena tutor merupakan salah satu aspek dasar dari efektivitas kelompok diskusi tutorial PBL. Dalam hal ini yaitu, memperhatikan kehadiran tutor disetiap kegiatan tutorial dan memperhatikan pembagian tutor tetap atau tutor yang sama untuk memfasilitasi setiap kelompok diskusi tutorial.

\section{DAFTAR PUSTAKA}

1. Andayani. Problema dan aksioma. (1st ed.). Yogyakarta: Deepublish, 2015; p. 85.Pengertian Metode Pembelajaran. Available from: http://seputarpendidikan003.blogspot. co.id/2013/06/pengertian-metodepembelajaran.html
2. Boud D, Feletti G. Chapter 1 introduction. The challenge of problem based learning. London: N1 9JN, 1991; p. 14.

3. Dolmans DHJM, Schmidt HG. What do we know about cognitive and motivational effects of small group tutorials in problem-based learning? Advances in Health Sciences Education. 2006;11:321-36.

4. Biologi Online.Metode Pembelajaran Kelompok Tutorial. 20 Juni 2009. (cited 12 Oktober 2015). Available from:

https://zaifbio.wordpress.com/2009/0 6/20/metode-pembelajarankelompok-tutorial/

5. Dent JA, Harden MR. 22 Problem-Based Learning. A Practical Guide for Medical Teachers. London, 2009; p.176-177. Available from: www.vietnhim.com.

6. Mewo YM, Widodo SOS, Prihartono J. Persepsi Mahasiswa Terhadap Efektivitas Kelompok Diskusi Tutorial ProblemBased Learning di Fakultas Kedokteran Universitas Sam Ratulangi Manado. Jurnal Perpipki. 2011;2:22-31.

7. Singaram VS. van der Vleuten CPM, van Berkel H. Reliability and validity of a tutorial groups effectiveness instrument. Medical Teacher. 2010;32:33 -137.

8. Iriantara Y. 5 Komunikasi Kelompok Dalam Pembelajaran. Komunikasi Pembelajaran Interaksi Komunikatif dan Edukatif di Dalam Kelas. Bandung: Simbiosa Rekatama Media, 2014; p. 131.

9. Roojakers. Mengajar dengan sukses. Indonesia: Gramedia Widiasarana, 2008; p. 76.

10. Gulo W. Strategi Belajar Mengajar. Jakarta: PT Grasindo, 2002; p. 127.

11. Kosasih E. Strategi Belajar Dan Pembelajaran Implementasi Kurikulum 2013. Yrama Widya, 2014 .p.88-101

12. Rahayu, Gandes Retno. Pembelajaran Berpusat Mahasiswa. Yogyakarta: Pusat pengembangan pendidikan Universitas Gadjah Mada, 2005; p. 36-43.

13. Vina L. Evaluasi diri Problem Based Learning (PBL) pada blok biomedik 
Jurnal e-Biomedik (eBm), Volume 4, Nomor 1, Januari-Juni 2016

5 mahasiswa semester 2 Fakultas Kedokteran Universitas Pattimura. Jurnal Kedokteran dan Kesehatan 2012;5(1):24-31.

14. Maanesh S. Siap Kuliah. Jakarta: Gagas Media, 2009; p. 35.
15. Badudu JS. Kamus Bahasa Indonesia. Jakarta: Pustaka Sinar Harapan, 1994; p. 271.

16. Hakim T. Belajar Secara Efektif. Jakarta: Puspa Swara, 2000; p. 29-31. 